Олексій Вікторович Алексеснко (канд. техн. наук, доент)

Олександр Олександрович Челобітченко (канд. техн. наук, с.н.с)

Національний університет оборони Украйни імені Івана Черняховського, Київ, Украйна

\title{
МІЖЛАБОРАТОРНІ ПОРІВНЯЛЬНІ ВИПРОБУВАННЯ ЗАСОБІВ КОЛЕКТИВНОГО ТА ІНДИВІДУАЛЬНОГО ЗАХИСТУ ДЛЯ ЗАБЕЗПЕЧЕННЯ ОЦІНКИ ЯКОСТІ ПРОДУКЦІЇ ОБОРОННОГО ПРИЗНАЧЕННЯ
}

\begin{abstract}
Розглянуто актуальні питання оцінки якості продукиії, щңо постачається для потреб Збройних Сил України, як однісї зі складових сектору безпеки і оборони держави, та ї̈ відповідності під час реформування оборонно-промислового комплексу держави, наведено вимоги до якості продукції оборонного призначення згідно з чинними в Украӥні стандартами при потребі досягнення євроатлантичних стандартів та критеріїв, необхідних для набуття членства в НАТО. Акцентовано увагу на питаннях визначення балістичної стійкості засобів колективного та індивідуального бронезахисту, що постачаються до складових сектору безпеки та оборони держави в умовах "гібридної війни”. Наведено результати міжлабораторних порівняльних випробувань зразків елементів захисту в акредитованій Національним агентством з акредитації України науково-випробувальній лабораторії. Доведено, щзо успішне проведення таких порівняльних випробувань є потенційно корисним для забезпечення ефективності оцінки якості продукиії для потреб сектору безпеки і оборони.

Ключові слова: сектор безпеки і оборони держави, оборонно-промисловий комплекс, продукція оборонного призначення, ефективність контролю якості продукції, міжлабораторні порівняльні випробування.
\end{abstract}

\section{Вступ}

Аналіз актуальних питань інноваційного розвитку економіки в державі, поширення досвіду та знань в інноваційній сфері, проблем комерціалізації науково-технічних розробок та трансферу технологій, світового досвіду та реалії впровадження інноваційних технологій [1-7], виявив низку проблем, притаманних сучасному оборонно-промисловому комплексу (ОПК) України, який є головним компонентом її воєнноекономічного потенціалу [1].

Тривалий час (3 моменту проголошення незалежності до початку “гібридної війни” проти України) ОПК поряд 3 іншими складовими сектору безпеки та оборони знаходився в умовах постійного суттєвого реформування та необхідності оновлення (трансформації) технологічної, виробничої бази.

Постановка проблеми. 3 метою якісного реформування ОПК виникла потреба розробки та впровадження ефективних державних програм 3 необхідним фінансуванням за рахунок державного бюджету. Однак, протягом тривалого часу спостерігалось критичне недофінансування потреб ОПК в реалізації таких програм, що стало причиною поверхневого реформування та накопичення проблем його перебудови. До того ж основними стратегічними керівними документами державного рівня не було враховано воєннополітичних та інших загроз навколо держави, а помилкові погляди щодо пріоритетності розвитку озброєння і військової техніки (ОВТ) для
Збройних Сил України уповільнило подальший розвиток оборонної реформи [10].

Незважаючи на ухвалення в Україні останніми роками основних стратегічних i концептуальних документів із питань оборони та безпеки держави (Воєнної доктрини, Стратегічного оборонного бюлетеня, Державної цільової програми реформування та розвитку оборонно-промислового комплексу України до 2021 року тощо), ситуація 3 реформуванням вітчизняного ОПК залишається складною.

Крім того, інтеграція України в європейський політичний, економічний, правовий простір визначено національним інтересом на законодавчому рівні [8], а одним 3 напрямів реформування Збройних Сил України $\epsilon$ забезпечення максимальної сумісності зі збройними силами держав-членів НАТО через запровадження стандартів. Державною програмою розвитку Збройних Сил України на період до 2020 року визначено мету - досягнення євроатлантичних стандартів та критеріїв, необхідних для набуття членства в НАТО. Одним iз шляхів досягнення мети $\epsilon$ стандартизація та кодифікація озброєння та майна відповідно до стандартів НАТО [8].

Прагнення інтегрування ОПК України у світову економіку (стосовно Збройних Сил України - ринок озброєнь), відкривають для країни нові можливості для партнерства, актуалізують необхідність гармонізації сучасної системи технічного регулювання відповідно до 
норм та правил Свропейського Союзу, країн членів НАТО, в рамках яких здійснюється організація виробництва конкурентоспроможної продукції за допомогою інноваційних технологій.

Загострення конкуренції, великий вплив політичних чинників, система міжнародного контролю за трансферами озброєнь та інші, вимагають від учасників ринку озброєнь застосовувати різноманітні стратегії просування своєї продукції та вдаватися до різних форм конкурентної боротьби.

Таким чином, особливої актуальності та значущості для держави набули питання формування національної інвестиційної системи, розробки, впровадження та комерціалізації інноваційних проектів у секторі безпеки і оборони, а внаслідок інноваційного пожвавлення серед виробників та постачальників військової продукції 3'являється проблема у здійсненні належного контролю за якістю зразків, що надходять до військових підрозділів сектору безпеки і оборони [9]. Одним 3 показників ефективності системи контролю якості таких зразків рахуються міжлабораторні порівняння результатів вимірювань, їх достовірність та точність.

Аналіз остатніх досліджень і публікацій. Останнім часом значно збільшується кількість як виробників продукції оборонного призначення (в тому числі засобів колективного та індивідуального бронезахисту), так і організмів, що забезпечують точність та достовірність результатів балістичних випробувань окремих партій таких виробів.

Загальним

науково-теоретичним підгрунтям досліджень визначення ефективності системи контролю якості засобів колективного та індивідуального бронезахисту, що постачаються до складових сектору безпеки та оборони держави, iз застосуванням міжлабораторних порівнянь результатів вимірювань балістичної стійкості їх елементів, займались багато відомих учених [11-15], серед яких Бондаренко Л. І., Кравець І. А., Степанов Г. В., Зубов В. I., Чепков I. Б., Королько С. В., Курташов В. П., в роботах яких розглядаються лише механізми взаємодії засобів ураження (куля, осколки) 3 елементами бронезахисту на основі використання теоретичних та імітаційних методів (моделей) з урахуванням вимог лише державних та галузевих стандартів.

В той же час розвиток національної системи сертифікації та стандартизації в Україні йде у напрямі iii гармонізації 3 міжнародними нормами і правилами.

Метою статті $\epsilon$ визначення підходів до підвищення якості, визначення балістичної стійкості засобів колективного та індивідуального бронезахисту, що постачаються до складових сектору безпеки та оборони держави в умовах “гібридної війни” проти України.

Виклад основного матеріалу дослідження. Вітчизняна нормативно-технічна документація щодо організації та проведення балістичних випробувань не гармонізована 3 міжнародною нормативно-технічною документацією, у якій відображені На думку авторів статті, незважаючи на велику кількість праць, присвячених проблемам балістичних випробувань, недостатньо розглянуті питання щодо забезпечення єдності їх результатів незалежно від часу та місця їх проведення, нормативно-технічна документація існує в розрізненому вигляді, не має загального наукового підгрунтя, особливо в частині врахування відмінностей організації випробувального процесу в лабораторіях поняттєво-термінологічні питання, вимоги з планування, організації, проведення випробувань та оброблення i подання їх результатів.

На сучасному етапі особливої актуальності набули питання оцінки якості продукції, що постачається для потреб Збройних Сил України, як однієї зі складових сектору безпеки і оборони держави, та ії відповідності.

Якість продукту, послуги визначено в ISO 9000-2000. Quality management systems Fundamentals and vocabulary [16] як здатність задовольняти потреби споживача.

Абсолютний рівень якості того чи іншого виробу знаходять шляхом обчислення вибраних для його вимірювання показників без їх порівняння 3 відповідними показниками аналогічних виробів. Визначення абсолютного рівня якості є недостатнім, оскільки само по собі не відображає ступеня його відповідності сучасним вимогам. Тому поряд 3 цим визначають відносний рівень якості окремих видів продукції, порівнюючи ii показники 3 абсолютними показниками якості кращих аналогічних вітчизняних і зарубіжних виробів. Проте рівень якості продукції під впливом науково-технічного прогресу й вимог споживачів повинен мати тенденцію до підвищення.

В Україні діє створена Держспоживстандартом України державна система сертифікації продукції УкрСЕПРО, нормативну базу якої складають державні стандарти України.

Відповідно до ст. 1 Закону України "Про стандарти, технічні регламенти та процедури оцінки відповідності” підтвердження відповідності - це діяльність, наслідком якої $\epsilon$ гарантування того, що продукція відповідає встановленим законодавством вимогам. Підтвердження відповідності застосовується на доринковій стадії введення продукції в обіг i здійснюється виробником як самостійно, так і 3 залученням третьої сторони - органа 3 сертифікації. Крім того, стандартизація i сертифікація $\epsilon$ нормативно-методичною базою забезпечення якості продукції i конкурентноздатності виробництва. Об'єктами стандартизації є продукція, процеси і послуги, 
зокрема матеріали, устаткування, системи, правила, процедури, функції, методи або діяльність. У процесі стандартизації виробляються норми, правила, вимоги, характеристики, що стосуються об'єкта стандартизації, які оформлюються у вигляді нормативного документа - стандарту.

$$
\text { Стандарти на методи контролю }
$$
(випробування, вимірювання, аналізу) рекомендують застосовувати методики контролю, що забезпечують об'єктивність оцінки обов'язкових вимог до якості продукції, які наведені в стандарті на продукцію. Головний критерій об'єктивності методу контролю (випробування, вимірювання, аналізу) відтворюваність і порівнянність результатів. Необхідно користуватися саме стандартизованими методами контролю, випробувань, вимірювань i аналізу, тому, що вони базуються на міжнародному досвіді і передових досягненнях.

Однак, оптимізація ціноутворення на продукцію оборонного призначення, встановлення фінансового компромісу між інтересами замовника та підприємствами, система розрахунків собівартості продукції, яка існує нині, не дає змоги підприємствам отримувати ринкові норми прибутку.

Завдяки глобалізації, конкуренції та насиченості ринку озброєнь, зазнали принципових змін вимоги до рівня якості продукції та послуг. В умовах розвитку міжнародної торгівлі успіх галузей економіки (в тому числі оборонної) на зовнішньому та внутрішньому ринках суттєво залежить від того, наскільки вони відповідають стандартам якості.

Тому, проблема забезпечення й підвищення якості продукції оборонного призначення актуальна, а від іï рішення значною мірою залежить ефективність національної економіки в цілому.

Досить актуальним залишаються питання якості, визначення балістичної стійкості засобів колективного та індивідуального бронезахисту, що постачаються до складових сектору безпеки та оборони держави в умовах "гібридної війни" проти України (рис. 1) [9].

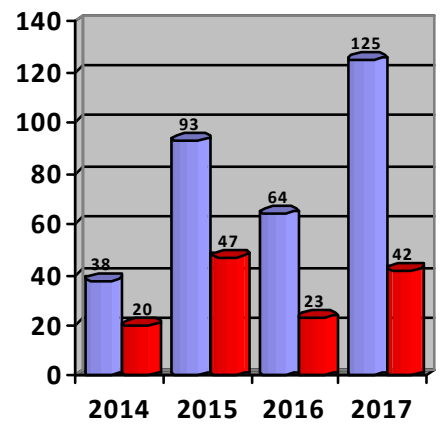

Рис 1. Результати балістичних випробувань кількості зразків продукції, наданої виробниками впродовж 2014-2017 років
Як видно 3 рис. 1, максимальна кількість невідповідності продукції, що перевірялась, діючим вимогам стандартів спостерігається на період активізації збільшення виробників та постачальників засобів колективного та індивідуального бронезахисту до складових сектору безпеки та оборони держави в умовах неконтрольованості якості продукції оборонного призначення.

Одним із головних елементів системи визначення захисних властивостей матеріалів, 3 яких виготовляються засоби індивідуального та колективного бронезахисту та показників якості продукції оборонного призначення $\epsilon$ випробування.

Враховуючи важливість результатів випробувань у сфері безпеки та оборони зрозумілою $\epsilon$ вимога щодо забезпечення необхідного рівня технічної компетентності випробувальних лабораторій. Оцінювання рівня технічної компетентності випробувальної лабораторії виконується через процедуру акредитації на відповідність вимогам національного стандарту [17], що здійснюється Національним агентством 3 акредитації України. Слід відмітити, що національний стандарт [17] $€$ ідентичним міжнародному стандарту [18], який використовується для акредитації лабораторій у всьому світі.

Для вирішення цього питання прийнято багато нормативних актів, що регулюють вимоги як до продукції, так і до органів, які здійснюють оцінку іiі якості. При цьому єдиним механізмом оцінки відповідності $€$ випробування, а орган оцінки відповідності - система випробувальних лабораторій (далі - ВЛ), до яких ставляться жорсткі вимоги, в тому числі щодо підтвердження професійного рівня. Ця система під час свого історичного розвитку пройшла багато етапів починаючи від безсистемної демонстрації засобів захисту, при якій були відсутні навіть критерії їх оцінки, і до розробки методів випробувань на державному та міжнародному рівнях.

На сьогодні діяльність випробувальних лабораторій регламентують стандарти: ДСТУ ISO/IEC 17025:2006 - у частині впровадження системи менеджменту якості та підтвердження технічної компетентності лабораторій, та ДСТУ ISO/IEC 5725:2005 - у частині забезпечення точності результатів, отриманих у випробувальній лабораторії. Вимоги стандарту є складними для успішної реалізації його в практиці випробувальних лабораторій.

Якість результатів випробувань визначається достовірністю результатів, які залежать від дотримування методик проведення випробувань.

Хоч би якою сучасною була лабораторія, право проводити випробування в системі сертифікації вона отримає лише після офіційного визнання піi компетентності. Акредитація лабораторії $є$ тим самим офіційним визнанням 
права на проведення певного переліку випробувань. Тільки після проходження акредитації органи, які пропонують послуги із сертифікації, визнають технічну компетентність лабораторії та об'єктивність отриманих результатів.

Першим кроком у підтвердженні відповідності щодо проведення випробування може бути атестація вимірювальної лабораторії у державній метрологічній системі. Спираючись на перелік обов'язкових вимог до випробувальних лабораторій, органи, уповноважені проводити атестацію, оцінюють стан справ у конкретній лабораторії за всіма заявленими в галузі показниками, починаючи від юридичного статусу та організаційної структури й закінчуючи аналізом протоколів випробувань, перевіркою дотримання інших вимог, які передбачає атестація. Та атестація вимірювальної лабораторії не може забезпечити всебічну простежуваність випробувань, а заходи з атестації не передбачають належної оцінки впровадженої системи якості в лабораторії. Тому доцільно забезпечувати заходи 3 попереднього проведення оцінки управління якістю до первинної акредитації лабораторії компетентним органом 3 оцінки відповідності в галузі акредитації.

Ефективною методикою, яка дозволяє достовірно оцінити компетентність випробувальних лабораторій та якість роботи ї персоналу, є міжлабораторні порівняльні випробування. Вони можуть наочно підтвердити точність проведених випробувань шляхом отримання оцінки тих самих продуктів або матеріалів відразу в декількох лабораторіях. Помилок тлумачення результатів у цих випробуваннях бути не може, оскільки всі вимірювання проводяться відповідно до попередньо встановлених умов. I, звичайно ж, головною вимогою тут стає можливість порівняти результати, отримані різними лабораторіями, які брали участь у процедурі порівняльних випробувань.

Успішна участь у програмах міжлабораторних порівняльних випробувань $\epsilon$ підставою для підтвердження якості випробувань, які проводить ВЛ. Для безперервного отримування даних випробувань лабораторіям необхідно постійно удосконалювати процедури у рамках системи управління відповідно до вимог стандарту ДСТУ ISO/IEC 17025:2006 [17], проводячи регулярний внутрішній контроль якості результатів випробування. Одним 3 показників ефективності системи контролю якості засобів колективного та індивідуального бронезахисту рахуються міжлабораторні порівняння результатів вимірювань, їх достовірність та точність. Участь у

\section{Лimepamypa}

1. Стратегія національної безпеки України, затверджена Указом Президента України від 26 травня 2015 року № 287/2015 [Електронний ресурс]. - Режим міжлабораторних порівняльних випробуваннях $\epsilon$ обов'язковим та невід'ємним елементом зовнішнього контролю системи управління випробувальної лабораторії. Це відіграє важливу роль як під час акредитації лабораторії, так і під час її функціонування.

На міжнародному рівні проведення міжлабораторних порівнянь регламентується стандартом [18], в якому наведено основні організаційні та методичні заходи, але відсутні дані щодо міжлабораторних порівнянь та оцінки їх результатів у разі відсутності стандартних зразків та застосуванні руйнівних методів випробувань, що є типовим для сфери безпеки та оборони.

В Збройних Силах України існує єдина ВЛ, яка акредитована в Національному агентстві 3 акредитації України відповідно до вимог ДСТУ ISO/IEC 17025:2006. Сфера акредитації наукововипробувальної лабораторії зброї та спеціальних захисних матеріалів дозволяє проводити балістичні випробування стійкості засобів індивідуального і колективного бронезахисту як за державними [19-22], так і за стандартами НАТО. Крім того, лабораторія виконує вимоги Національного агентства 3 акредитації України щодо між лабораторних порівняльних випробувань.

Точність вимірювання швидкості польоту кулі для пістолетів ПМ, ТТ, автомата АК-74, гвинтівки СВД за результатами міжлабораторних порівняльних випробувань 3 Державним науководослідним інститутом Міністерства внутрішніх справ України наведено на рис. 2.
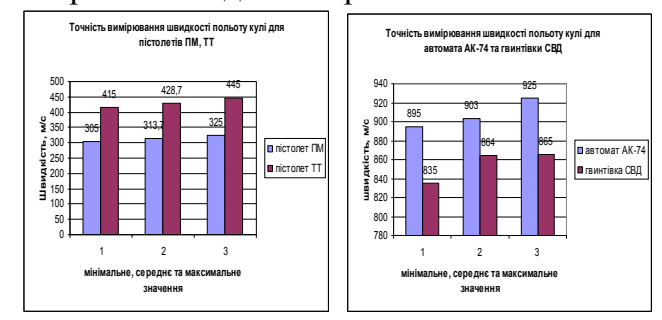

Рис. 2. Точність вимірювання швидкості польоту кулі для різної зброї

Як видно 3 рис. 2, середні значення вимірювання швидкості польоту кулі для різної зброї відповідають вимогам, встановленим нормативною документацією.

\section{Висновки й перспективи подальших досліджень.}

Таким чином, міжлабораторні порівняльні випробування, що здійснює наукововипробувальна лабораторія зброї та спеціальних захисних матеріалів є потенційно корисними для оборонної промисловості, а для подальшого розвитку їх ефективності потрібно застосовувати нові стратегії наукового пошуку.

доступу: http://zakon5.rada.gov.ua/laws/show/389/2012. 2. Розпорядження Кабінету Міністрів України "Про схвалення Концепції розвитку національної 
інноваційної системи” від 17 червня 2009 року № 680-р [Електронний ресурс]. - Режим доступу: http://zakon3.rada.gov.ua/laws/show/ 680-2009-p. 3. Руснак I. C. Воєнна безпека України у світлі реформування сектора безпеки i оборони // Наука i оборона. - 2015. - № 2. - С. 9-14. 4. Чепков I. Б. Основні шляхи реформування вітчизняного обороннопромислового комплексу в ринкових умовах / І.Б.Чепков, А.С.Довгополий, М.І.Луханін, В.С.Сіренко // Озброєння та військова техніка. - 2015.-№ 1 (5). - С. 3-11. 5. Шевцов А. І. Стратегічні підходи до вибору інноваційної моделі розвитку оборонно-промислового комплексу України / А.І.Шевцов, Р.В.Боднарчук // Стратегічна панорама. - 2008. - № 1. - С. 108-112. 6. Шевцов А. І. Концептуальні підходи до реалізації моделі інноваційної розвитку оборонно-промислового комплексу України / А.І.Шевцов, Р.В.Боднарчук // Стратегічна панорама. - 2009. - № 2. - С. 156-163. 7. Шевцов А. І. Актуальні проблеми реструктуризації оборонно-промислового сектору економіки України / А.І.Шевцов, Р.В.Боднарчук // Стратегічні пріоритети. 2013. - № 2. - С. 127-134. 8. Державна програма розвитку Збройних Сил України на період до 2020 року // Міністерство оборони України. 9. Балістичні випробування засобів колективного та індивідуального захисту - завершення дослідницької стадії інноваційних проектів 3 їх створення / О.О.Челобітченко, О.В.Алексеєнко, В.А.Курбан, С.Г.Сєдов // Наука і оборона, 2018, № 1. С. 49-56 . 10. В. П. Горбулін, В. С. Шеховцов, А. І. Шевцов. ОПК України: кроки до стабілізації діяльності та розвитку в умовах гібридної війни. // Стратегічна панорама. - 2016. - № 2 . - С. 54-62. 11. Франчук В. І., Вінник І. Ю. Розвиток національного ринку озброєнь як запорука обороноздадтності сектору ОПК України. // Комунальне господарство міст, 2017, випуск 133, с. 13-18 12. Чепков I. Б. Проблеми технічного оснащення Збройних Сил України та шляхи їх розв'язання в сучасних умовах / І.Б.Чепков, І.В.Борохвостов, В.К.Борохвостов, А.О.Русевич // Наука і оборона. 2014. - № 3. - С. 43-50. 13. Королько С. В. Аналіз і оцінка можливостей застосування сучасних матеріалів для броньованої техніки та захисту особового складу від ураження / Системи озброєння і військової техніки. - Х.: ХУПС, 2015. - № 2 (42). - С. 163-167. 14. Курбан В. А. Проблемы выбора элементов индивидуальной и коллективной броневой защиты / В.А.Курбан, В.А.Бублий, В.П.Курташов, В.П.Сахно // Артиллерийское и Стрелковое Вооружение. - К.: КБ “Артиллерийское вооружение”, - 2012. - № 2 (43). С. 25-30. 15. А. І. Коробко, О. О. Михайлова, О. О. Назарько, Ю. А. Радченко. Управління якістю випробувань автотракторної техніки 3 використанням нечіткої логіки // ВІСНИК ЖДТУ. 2016. № 2 (77). C. 109-114. 16. ISO 9000-2000. Quality management systems - Fundamentals and vocabulary. - (Системи управління якістю. Основні принципи та словник). 17. ДСТУ ISO/IEC 17025 “Загальні вимоги до компетентності випробувальних та калібрувальних лабораторій". 18. Стандарт HATO "STANAG 2920 PPS (EDITION 2)”. 19. ДСТУ В 4103-2002 “Засоби індивідуального захисту. Бронежилети. Загальні технічні умови". 20. ДСТУ В 4104-2002 “Засоби індивідуального захисту. Вироби бронезахисту. Методи контролю балістичної стійкості бронежилетів". 21. ГСТУ 78-41-004-97 “Шоломи для захисту від куль. Загальні технічні умови”. 22. ДСТУ 3975-2000 “Захист панцеровий спеціалізованих автомобілів. Загальні технічні вимоги".

\title{
МЕЖДУЛАБОРАТОРНЫЕ СРАВНИТЕЛЬНЫЕ ИСПЫТАНИЯ СРЕДСТВ КОЛЛЕКТИВНОЙ И ИНДИВИДУАЛЬНОЙ ЗАЩИТЫ ДЛЯ ОБЕСПЕЧЕНИЯ ОЦЕНКИ КАЧЕСТВА ПРОДУКЦИИ ОБОРОННОГО НАЗНАЧЕНИЯ
}

\author{
Алексей Викторович Алексеенко (канд. техн. наук, доцент) \\ Александр Александрович Челобитченко (канд. техн. наук, с.н.с.)
}

\section{Национальный университет обороны Украины имени Ивана Черняховского, Киев, Украина}

Рассмотрены актуальные вопросы оценки качества продукиии, которая поставляется для нужд Вооруженных Сил Украины, как одной из составляющих сектора безопасности и обороны государства, та ее соответствия при реформировании оборонно-промышленного комплекса государства, приведены требования к качеству продукции оборонного назначения в соответствии с существующими в Украине стандартами при необходимости достижения евроатлантических стандартов и критериев, необходимых для приобретения членства в НАТО. Акиентировано внимание на вопросах определения баллистической стойкости средств коллективной и индивидуальной защитыл, которые поставляются 8 составляющие сектора безопасности и обороны государства в условиях “гибридной войны”. Приведень результаты междулабораторных сравнительных испытаний образцов средств коллективной и индивидуальной защиты в аккредитованой Нацииональным агентством по аккредитации Украинь научно-испытательной лаборатории. Доведено, что успешное проведение таких сравнительных испытаний есть потенциально полезным для обеспечения эффективности оценки качества продукиии для нужд сектора безопасности и обороны.

Ключевые слова: сектор безопасности и обороны государства; оборонно-промышленный комплекс; продукиия оборонного назначения; эффективность контроля качества продукции; междулабораторные сравнительные испытания.

\section{INTERLABORATORY COMPARATIVE TESTING OF COLLECTIVE AND INDIVIDUAL PROTECTION EQUIPMENT TO ENSURE THE ASSESSMENT OF THE QUALITY OF DEFENSE PRODUCTS}

\author{
Aleksey V. Alekseenko (Ph.D, Assistant Professor)
}


Aleksandr A. Chelobitchenko (Ph.D, Senior Researcher)

\section{National Defence University of Ukraine named after Ivan Cherniakhovsky, Kiev}

The topical issues of product quality assessment, which is supplied for the needs of the Armed Forces of Ukraine, as one of the components of the security and defense sector of the state, are considered. Consideration is also given to the conformity of these products in the reform of the state's defense-industrial complex. The same requirements are given to the quality of defense products in accordance with the existing standards in Ukraine, if it is necessary to achieve Euro-Atlantic standards and the criteria necessary for acquiring NATO membership. The attention is focused on the issues of determining the ballistic durability of collective and individual defense equipment that are supplied to the relevant security and defense sectors of the state in the conditions of a "hybrid war". The results of interlaboratory comparative tests of samples of collective and individual protection equipment in the accredited scientific laboratory of the National Accreditation Agency of Ukraine. It has been proven that the successful conduct of such comparative tests is potentially useful for ensuring the effectiveness of product quality assessment for the needs of the security and defense sector.

Key words: security and defense sector of the state; defense-industrial complex; defense products; efficiency of product quality control; interlaboratory comparative tests.

\section{References}

1. The Strategy of National Security of Ukraine, approved by the Decree of the President of Ukraine dated May 26, 2015, No. 287/2015 [Electronic resource]. - Access mode: http://zakon5.rada.gov.ua/laws/show/389/2012. 2. Order of the Cabinet of Ministers of Ukraine "On Approval of the Concept of Development of the National Innovation System" dated June 17, 2009 No. 680-r [Electronic Resource]. - Mode of access: http://zakon3.rada.gov.ua/laws/show/ 680-2009-p. 3. Rusnak I. S. Military Security of Ukraine in the Light of Reforming the Security and Defense Sector // Science and Defense. - 2015. - No. 2. - S. 9-14. 4. Chepkov I. B. The main ways of reforming the domestic defense-industrial complex in market conditions / I. B. Chepkov, A. S. Dovgopoly, M. I. Lukhanin, V. Y. Sirenko // Arms and military equipment. - 2015. № 1 (5). - P. 3-11. 5. Shevtsov A. I. Strategic Approaches to Choosing an Innovative Model for the Development of the Defense Industrial Complex in Ukraine / A. I. Shevtsov, R. V. Bodnarchuk // Strategic Panorama. - 2008. - No. 1. - P. 108112. 6. Shevtsov A. I. Conceptual approaches to the implementation of the model of innovation development of the defense industrial complex of Ukraine / A. I. Shevtsov, R.V. Bodnarchuk // Strategic Panorama. - 2009. - No. 2. P. 156-163. 7. Shevtsov A. I. Actual Problems of Restructuring of the Defense Industrial Sector of the Ukrainian Economy / A. I. Shevtsov, R. V. Bondarchuk // Strategic Priorities. - 2013. - № 2. - P. 127-134. 8. State Program of Development of the Armed Forces of Ukraine for the period up to 2020 // Ministry of Defense of Ukraine. 9. Ballistic tests of means of collective and individual protection - completion of the research stage of innovative projects for their creation / O. O. Chelobichenko, O. V. Alekseenko, V. A. Kurban, S. G. Sedov // Science and defense, 2018, No. 1 P. 49-56. 10. V. P. Gorbulin, V. S. Shekhovtsov, A. I. Shevtsov. Ukrainian Defense Complex: Steps to Stabilize and Develop in Hybrid
Warfare. // Strategic panorama. - 2016. - No. 2. - P. 54-62. 11. Franchuk V.I., Vinnik I. Yu. The development of the national arms market as a pledge of defensive capability of the sector of the Ukrainian defense industry. // Municipal economy of cities, 2017, issue 133, p. 13-18. 12. Chepkov I. B. Problems of technical equipment of the Armed Forces of Ukraine and ways of their solution in modern conditions / I. B. Chepkov, I. V. Borohvostov, V. K. Borokhovostov, A. O. Rusevich // Science and defense. - 2014. - No. 3. - P. 43-50. 13. Korolko S. V. Analysis and evaluation of the possibilities of using modern materials for armored vehicles and personnel protection against defeat / Systems of armament and military equipment. - Х.: ХУПС, 2015. - № 2 (42). - Р. 163-167. 14. Kurban V. A. Problems of the selection of elements of individual and collective armor protection / V. A. Kurban, V. A. Bubly, V. P. Kurtashov, V. P. Sahno // Artillery and Strelkovoi Armament. - K .: KB "Artillery armament", 2012. - No. 2 (43). - pp. 25-30. 15. A. I. Korobko, O. O. Mikhailova, O. O. Nazarko, Yu. A. Radchenko Quality control of automotive tractor testing using fuzzy logic // HISTORY OF ZHDTU. 2016. No. 2 (77). P. 109114. 16. ISO 9000-2000. Quality management systems Fundamentals and vocabulary. - (Quality Management Systems - Basic Principles and Dictionary). 17. DSTU ISO / IEC 17025 "General requirements for the competence of testing and calibration laboratories". 18. NATO Standard "STANAG 2920 PPS (EDITION 2)". 19. DSTU 4103-2002 "Personal protective equipment. Armor General specifications ". 20. DSTU 4104-2002 "Personal protective equipment. Armor protection products. Methods of controlling the ballistic stability of body armor ". 21. GOST 78-41-004-97 "Helmets for protection from bullets. General specifications". 22. DSTU 3975-2000 "Protecting the Panzer Specialized Vehicles. General technical requirements ". 